\title{
Leptin stimulation of cell cycle and inhibition of apoptosis gene and protein expression in OVCAR-3 ovarian cancer cells
}

\author{
Anna Ptak • Elzbieta Kolaczkowska • \\ Ewa L. Gregoraszczuk
}

Received: 29 March 2012/Accepted: 30 August 2012/Published online: 12 September 2012

(C) The Author(s) 2012. This article is published with open access at Springerlink.com

\begin{abstract}
The OVCAR-3 cell line expressing the long $(\mathrm{ObRb})$ and short (ObRt) isoforms of leptin receptor mRNA was used to analyze the effect of leptin on the expression of selected genes and proteins involved in the cell cycle and apoptosis. OVCAR-3 cells were exposed to 2, 20, 40, and $100 \mathrm{ng} / \mathrm{ml}$ of leptin. Cell proliferation was determined using the alamarBlue cell viability test and flow cytometry. Apoptosis was measured using a cellular DNA fragmentation ELISA kit. The expression of selected cell cycle and apoptosis genes was evaluated by real-time PCR and confirmed by western blot. The stimulatory action of leptin on cell proliferation was observed as an increase in cells in the $\mathrm{S}$ and $\mathrm{G} 2 / \mathrm{M}$ phases. Up-regulation of genes responsible for inducing cell proliferation and suppression of genes responsible for inhibition of proliferation were noted. Western blots revealed increased expression of cyclins D and A and inhibition of p21WAF1/CIP1 protein expression by leptin. Inhibition of DNA fragmentation was observed under all leptin doses. Suppression of genes involved in the extrinsic and intrinsic apoptotic pathway was observed. Western blots illustrated decreased Bad, TNFR1, and caspase 6 protein expression in response to leptin treatment. Leptin promotes ovarian cancer cell line growth by up-regulating genes and proteins responsible for inducing cell proliferation as well as down-regulating pro-
\end{abstract}

\footnotetext{
A. Ptak $(\bowtie) \cdot$ E. L. Gregoraszczuk

Department of Physiology and Toxicology of Reproduction, Chair of Animal Physiology, Jagiellonian University, Gronostajowa 9, 30-387 Krakow, Poland

e-mail: anna.ptak@uj.edu.pl

E. Kolaczkowska

Department of Evolutionary Immunology, Institute of Zoology, Jagiellonian University, Gronostajowa 9, 30-387 Krakow, Poland
}

apoptotic genes and proteins in apoptotic pathways. Results of this study warrant examining the relationship between the risk of ovarian cancer and elevated leptin levels in obese women.

Keywords Leptin - Apoptosis - Cell cycle . OVCAR-3 cell

\section{Introduction}

Leptin is a multifunctional peptide hormone with wideranging biologic activities, including appetite regulation, bone formation, reproductive function, and angiogenesis. Circulating levels of leptin are strongly correlated to body fat content and are markedly elevated in obese compared with normal-weight individuals [1, 2]. Plasma leptin levels have been reported to be higher in overweight and obese women $(37.7 \mathrm{ng} / \mathrm{ml})$ than in normal-weight women (3.92-16.9 ng/ml) [2-4]. In some obese individuals, leptin levels can reach $100 \mathrm{ng} / \mathrm{ml}$ [5]. Interestingly, recent studies have demonstrated that leptin stimulates growth, migration, invasion, and angiogenesis in tumor cell models, suggesting that it can promote an aggressive cancer phenotype [6, 7]. Epidemiological studies have suggested a positive correlation between obesity and increased risk of different cancers, including ovarian cancer [8-10]. Several studies have addressed the possible role of leptin, the product of the obesity gene $(\mathrm{Ob})$, in ovarian cancer development and progression [11-13]. A recent study by Uddin et al. [13] showed a significant association between leptin receptor $(\mathrm{Ob}-\mathrm{R})$ overexpression and poor progression-free survival in $59.2 \%$ of epithelial ovarian cancers. In vitro studies have demonstrated that leptin induces proliferation in the ovarian cancer cell line BG-1 [11, 12], and it has been 
shown to inhibit apoptosis in ovarian epithelial cancer cell lines SKOV3 and MDAH2774 [13]. Accumulating evidence indicates that leptin has an effect on ovarian cancer growth, but information on its molecular mechanism with respect to regulation of the cell cycle and apoptosis is limited.

Based on the data of Choi et al. [11], who characterized both long $(\mathrm{ObRb})$ and short (ObRt) isoforms of leptin mRNA, as well as our previous study [14] showing protein expression of both isoforms of the leptin receptor in the immortalized OVCAR-3 ovarian cancer cell line, we used this cell line to analyze the effect of leptin on the expression of selected genes involved in the cell cycle and apoptosis.

\section{Materials and methods}

\section{Reagents}

RPMI 1640 medium without phenol red, fetal bovine serum (FBS, heat-inactivated), penicillin, streptomycin, and trypsin EDTA were obtained from PAA Laboratories $\mathrm{GmbH}$ (Colbe, Germany). Human leptin, bovine serum albumin (BSA), and trypan blue were obtained from Sigma Chemical Co., (St. Louis, MO, USA).

\section{Cell culture and treatments}

The human ovarian epithelial carcinoma cell line OVCAR3 was obtained from the American Type Culture Collection (Manassas, VA, USA). The cells were routinely cultured in RPMI 1640 medium without phenol red supplemented with $50 \mathrm{U} / \mathrm{ml}$ penicillin, $50 \mu \mathrm{g} / \mathrm{ml}$ streptomycin, and $10 \% \mathrm{v} / \mathrm{v}$ heat-inactivated FBS in a humidified incubator with $5 \%$ $\mathrm{CO}_{2}$ at $37^{\circ} \mathrm{C}$. The cells were switched to medium without serum $24 \mathrm{~h}$ before each experiment.

\section{Cell proliferation}

Cell proliferation was measured using the alamarBlue cell viability reagent (Invitrogen, Paisley, UK) according to the manufacturer's instructions. The cells were seeded in 96-well culture plates at a density of $1.5 \times 10^{4} \mathrm{cell} /$ well and then incubated in RPMI 1640 supplemented with $5 \%$ FBS as a control medium or with four different doses (2, 20,40 , and $100 \mathrm{ng} / \mathrm{ml}$ ) of leptin for 24,48 , and $72 \mathrm{~h}$. The medium was changed daily, adding new medium and new test compounds. The alamarBlue stock solution was aseptically added to the wells after 24,48 , and $72 \mathrm{~h}$ of culture in amounts equal to $10 \%$ of the incubation volume. Resazurin reduction was determined after $4 \mathrm{~h}$ of incubation by measuring the fluorescence at $560 \mathrm{~nm}$ (excitation)/590 nm (emission) using an FLx800 fluorescence microplate reader (BioTek, Winooski, VT, USA).

Flow cytometry analyses

The cells were seeded in 6-well culture plates at a density of $0.5 \times 10^{6}$ cell/well in RPMI 1640 supplemented with $5 \%$ FBS as a control medium or with $40 \mathrm{ng} / \mathrm{ml}$ of leptin for 24 and $48 \mathrm{~h}$. For analysis of cell proliferation, cell samples were stained with propidium iodide (PI). Briefly, after centrifugation $\left(10 \mathrm{~min}\right.$ at $\left.1,500 \mathrm{rpm}, 4{ }^{\circ} \mathrm{C}\right)$, the cell pellets were adjusted to $1 \times 10^{6} \mathrm{cell} / \mathrm{ml}$ and re-suspended in the PI staining buffer. The buffer contained $7.5 \times 10^{-5} \mathrm{M}$ PI, $10 \mathrm{mM}$ Tris base, $10 \mathrm{mM} \mathrm{NaCl}, 700 \mathrm{U} / 1$ RNase, $0.1 \mathrm{ml} / 100 \mathrm{ml}$ Nonidet P-40 (all from SigmaAldrich Chemical Co., St. Louis, MO, USA) and was adjusted to $\mathrm{pH}$ 8.0. The re-suspended cell pellets were kept in the buffer for $30 \mathrm{~min}$ in the dark at $4{ }^{\circ} \mathrm{C}$. Samples were then analyzed in a FACScalibur flow cytometer (BectonDickinson, San Jose, CA, USA) to assess the cell cycle DNA profile. In total, 20,000 threshold events per sample were collected and analyzed based on their FL2 fluorescence (emission at $585 \mathrm{~nm}$, excitation at $488 \mathrm{~nm}$ ). The resulting data were analyzed using CellQuest Pro software (Becton-Dickinson). Percentages of cells present in the various phases of the cell cycle were calculated using Cell Quest by gating for the following cell populations: A (apoptotic cells; $<2 n$ ), G1/G0 [cells in gap 1 (G1) and entering into the quiescent phase (G0); $2 n], \mathrm{S}$ (cells in the DNA synthesis phase; $>2 n$ ), and $\mathrm{G} 2+\mathrm{M}$ [cells in gap 2 $(\mathrm{G} 2 ; 4 n)$, and entering into the mitotic phase $(\mathrm{M} ;<4 n)]$.

\section{Bromodeoxyuridine (BrdU) incorporation assay}

DNA fragmentation was determined using the Cellular DNA Fragmentation ELISA Kit (Roche Applied Science, Mannheim, Germany). This assay is based on the quantitative detection of BrdU-labeled DNA fragments. After exposure to BrdU for $18 \mathrm{~h}$, the cells were re-seeded in 96-well culture plates at $1.5 \times 10^{4}$ cell/well and then incubated in RPMI 1640 as a control medium or with leptin at concentrations of 2, 20, 40, and $100 \mathrm{ng} / \mathrm{ml}$. After $24 \mathrm{~h}$, DNA fragmentation was determined according to the manufacturer's instructions. Absorbance values were measured spectrophotometrically at $450 \mathrm{~nm}$ using an ELx808 ELISA reader (BioTek).

\section{Real-time PCR analysis}

Cells were seeded in 6-well culture plates at $1 \times 10^{6}$ cell/ well in RPMI 1640 supplemented with $5 \%$ FBS (for cell cycle analysis) or without serum (for apoptosis analysis) as the control medium, or with $40 \mathrm{ng} / \mathrm{ml}$ of leptin for $24 \mathrm{~h}$. 
The choice of this dose was based on previous cell proliferation experiments. Total RNA from OVCAR-3 cells was isolated using the High Pure RNA Isolation Kit (Roche Applied Science). RNA purity and quantity were determined spectrophotometrically according to optical densities at 260 and $280 \mathrm{~nm}$. cDNA synthesis was performed using the Transcriptor First Strand cDNA Synthesis Kit (Roche Applied Science) with a mixture of anchored-oligo $(\mathrm{dT})_{18}$ primers and random hexamer primers according to the manufacturer's protocol. Amplifications were performed in duplicate using the LightCycler 480 System (Roche Applied Science) and the Real-Time Ready Human Apoptosis Panel and Real-Time Ready Human Cell Cycle Regulation Panel (Roche Applied Science) in combination with the LightCycler 480 Probes Master (Roche Applied Science) according to the manufacturer's instructions. PCR was performed in a final volume of $20 \mu \mathrm{l}$, including $50 \mathrm{ng}$ cDNA per reaction. The PCR conditions were as follows: pre-incubation for $10 \mathrm{~min}$ at $95^{\circ} \mathrm{C}$, amplification for 45 cycles $\left(10 \mathrm{~s}\right.$ at $95{ }^{\circ} \mathrm{C}, 30 \mathrm{~s}$ at $60^{\circ} \mathrm{C}$, and $1 \mathrm{~s}$ at $\left.72{ }^{\circ} \mathrm{C}\right)$. A positive control (to check for RNA degradation) and negative control (to detect residual genomic DNA) were run simultaneously with every assay according to the manufacturer's protocol. The relative expression of the analyzed genes was normalized to seven reference genes in the panel using the E-Method from Roche Applied Science, which analyzes the amplification efficiency of target and reference genes using relative standards. These standards are serial dilutions of a single sample (for example, undiluted, $1: 10,1: 100$, and so on), where the concentration is expressed in relative units (for example, 1, 0.1, 0.01, and so on). Using dilutions to generate a standard curve, the E-Method avoids the time-consuming preparation of artificial or cloned standards and the determination of their absolute values [15].

\section{Western blot analysis}

The cells were seeded in 24-well culture plates at $1 \times 10^{5}$ cell/well in RPMI 1640 supplemented with $5 \%$ FBS (for cell cycle analysis) or without serum (for apoptosis analysis) as the control medium, or with leptin at $40 \mathrm{ng} / \mathrm{ml}$ for 24 and $48 \mathrm{~h}$. The cells were washed with ice-cold PBS and lysed in ice-cold buffer. The protein concentration of the cell lysate was determined by Bradford reagent (Bio-Rad Protein Assay, Bio-Rad Laboratories, Munchen, Germany). Protein (30 $\mu \mathrm{g}$ from each treatment group) was separated by 10 and $15 \%$ SDS-PAGE and transferred to PVDF membranes using a Bio-Rad Mini-Protean 3 apparatus (Bio-Rad Laboratories). The blots were blocked for $2 \mathrm{~h}$ with $5 \% \mathrm{w} / \mathrm{v}$ BSA and $0.1 \% \mathrm{v} / \mathrm{v}$ Tween 20 in $0.02 \mathrm{M}$ Tris Buffered Saline buffer (TBS). The blots were incubated overnight at $4{ }^{\circ} \mathrm{C}$ with antibodies specific for cyclin D1, cyclin A, p21 Waf1/Cip1, TNFR1, caspase 6, and Bad from Cell Signaling Technology (Danvers, MA, USA). Loading controls consisted of immunoblotting the same membranes with $\beta$-actin antibody (Sigma Chemical Co.,). After incubation with the primary antibody, the membranes were washed three times and incubated for $1 \mathrm{~h}$ with a horseradish peroxidase-conjugated secondary antibody from Cell Signaling Technology for cyclin D1, cyclin A, p21 Waf1/Cip1, TNFR1, caspase 6, and Bad (from DakoCytomation, Glostrup, Denmark) for $\beta$-actin. Immunopositive bands were visualized using Western Blotting Luminol Reagents (Santa Cruz Biotechnology Inc., Santa Cruz, CA, USA) and quantified using densitometry analysis (EasyDens, Cortex Nowa, Poland).

\section{Statistical analysis}

Data were expressed as mean \pm SEM from four independent experiments performed in triplicate. Statistical analyses were performed using GraphPad Prism 5. Data were analyzed by one-way analysis of variance (ANOVA) followed by Tukey's honestly significant difference (HSD) multiple range test. A value of $P<0.05$ was considered statistically significant.

\section{Results}

Cell proliferation (alamarBlue assay)

Growth of OVCAR-3 cells in response to various doses of leptin was tested for 24, 48, and $72 \mathrm{~h}$. An increase in cell proliferation was noted under all leptin doses at $48 \mathrm{~h}$ of treatment (1.3-fold; $P<0.05$; Fig. 1), with 2 and $20 \mathrm{ng} / \mathrm{ml}$ of leptin at $72 \mathrm{~h}$ of treatment (1.3-fold; $P<0.05$; Fig. 1$)$,

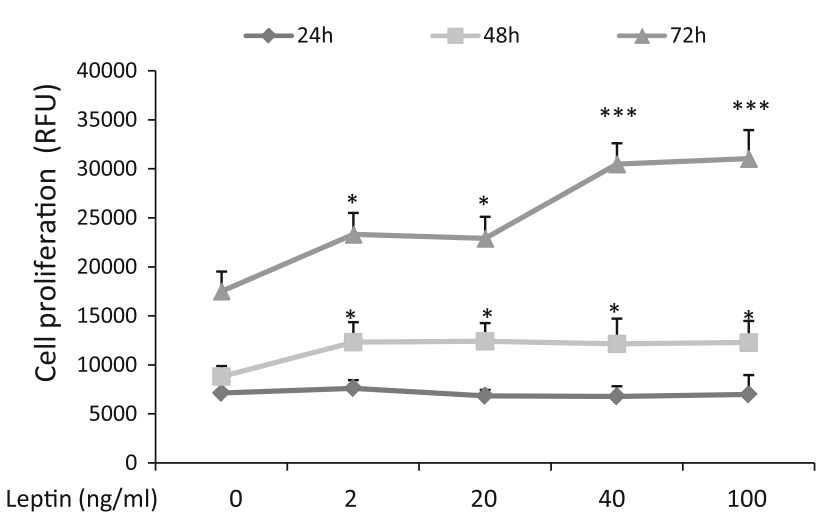

Fig. 1 Effects of leptin on OVCAR-3 cell proliferation. The cells were treated with leptin at $2,20,40$, and $100 \mathrm{ng} / \mathrm{ml}$ for 24,48 , and $72 \mathrm{~h}$ and then analyzed using the alamarBlue assay. Values are mean \pm SEM. $* * * *$ Significantly different from control at $P<0.05$ and $P<0.001$, respectively 
and with 40 and $100 \mathrm{ng} / \mathrm{ml}$ of leptin at $72 \mathrm{~h}$ of treatment (1.6-fold; $P<0.001$; Fig. 1). The sub-maximal leptin dose $(40 \mathrm{ng} / \mathrm{ml})$ was chosen for subsequent experiments.

Distribution in the cell cycle (flow cytometry)

Figure 2 presents the distribution of cells in the various phases of the cell cycle. In the controls, most OVCAR-3 cells were in the G0/G1 phase at any given point of time. At $48 \mathrm{~h}$, significantly different percentages of cells were in the $\mathrm{S}$ phase (DNA content $2-4 n ; 13.16 \pm 0.40 \%$ for leptin-treated cells vs. $10.99 \pm 0.28 \%$ for the control) and $\mathrm{G} 2+\mathrm{M}$ phase $(4 n ; 22.76 \pm 0.38$ for leptin-treated cells vs. $20.08 \pm 0.62 \%$ for the control $)(P<0.05$; Fig. 2a, b).

\section{Cell cycle gene expression analysis}

A 1.2- to 1.9-fold induction of G1/S-specific cyclin D1 (CCND1), G2/mitosis-specific cyclin A2 (CCNA2), transcription factors E2F3 (E2F3), and proliferating cell nuclear antigen (PCNA) (all genes inducing cell proliferation) was measured in cells exposed to leptin. In parallel, 1.9- and 1.2-fold suppressions of cyclin-dependent kinase inhibitor p21 (P21CIP1) and p27 (P27KIP1), respectively, and a 1.2-fold suppression of growth arrest and DNAdamage-inducible protein GADD45 alpha (GADD45A) (genes inhibiting proliferation) were observed. No change was found in the levels of cell division protein kinases 1 $(C D K 1), 4(C D K 4)$, and 6 (CDK6), wee1-like protein kinase (WEE1), or transcription factors E2F1 (E2F1) or E2F2 (E2F2). We also noted no change in the levels of the S-phase regulatory protein cyclin E (CCNE2, CCNE2) or its partner protein $\mathrm{CDK} 2(C D K 2)$, or in $\mathrm{G} 2 /$ mitotic-specific cyclin B1 $(C C N B 1)(P<0.05, P<0.001$; Table 1).

\section{Cell cycle protein expression analysis}

The protein expression of $C C N D 1, C C N A 2$, and P21CIP1, the most changed genes during the cell cycle, was analyzed by western blot. As with the genes' expression, an increase in cyclin D1 (an S-phase-associated protein) and cyclin A2 (a G2/M-phase-associated protein) and a decrease in p21WAF1/CIP1 (inhibitor of S-phase-associated protein) expression following leptin treatment were noted $(P<0.01, P<0.001$; Fig. 3a-c) .

\section{Apoptosis analysis by DNA fragmentation}

The statistically significant inhibition of DNA fragmentation to $84,82,75$, and $74 \%$ of control values was observed with leptin treatments of $2,20,40$, and $100 \mathrm{ng} / \mathrm{ml}$, respectively $(P<0.05, P<0.01$; Fig. 4$)$.
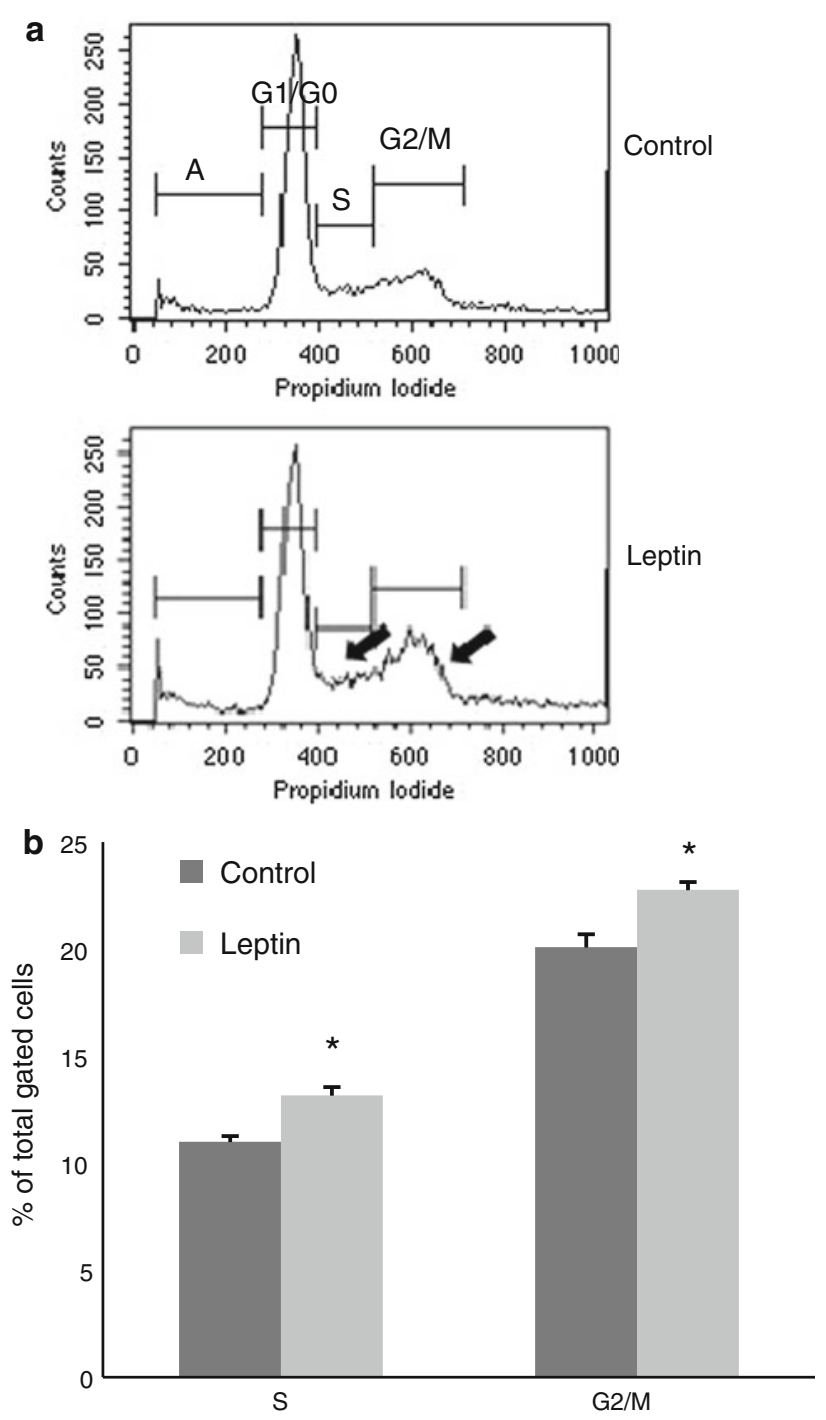

Fig. 2 Effects of leptin $(40 \mathrm{ng} / \mathrm{ml})$ on cellular DNA content and cell proliferation. a Representative histograms as estimated by flow cytometry after propidium iodide staining. $G 0 / G 1$ resting phase, in preparation for S; $S$ DNA synthesis phase; $G 2+M$ cells in gap 2 and entering into the mitotic phase; $A$ apoptotic cells. Arrows indicate peaks of $\mathrm{S}$ and $\mathrm{G} 2+\mathrm{M}$ cells. b Relative percentages of the cell population in $\mathrm{S}$ and $\mathrm{G} 2 / \mathrm{M}$ phase are presented in the total gated cell numbers. Values are mean \pm SEM. *Significantly different from the control at $P<0.05$

Apoptotic gene expression analysis

As shown in Table 2, leptin had no effect on FAS, CRADD, caspase 2 (CASP2), or caspase 8 (CASP8) mRNA levels, whereas we observed 1.4- to 1.8-fold suppression of TNFR1, FADD, and caspase 10 (CASP10). These results suggest a lack of activation of the Fas-dependent apoptotic pathway and inhibition of the TNFR apoptotic pathways. All of these genes are involved in the extrinsic apoptotic pathway. A 1.2-fold suppression of caspase 9 (CASP9) and 2.0-fold suppression of the gene expression of its partner 
Table 1 Changes in selected cell cycle genes' expression in OVCAR-3 cells exposed to $40 \mathrm{ng} / \mathrm{ml}$ leptin for $24 \mathrm{~h}$

\begin{tabular}{|c|c|c|c|c|}
\hline Assay ID & Transcript & Description & Gene symbol & Average fold change \\
\hline \multicolumn{5}{|c|}{ G1/S phase } \\
\hline 100844 & ENST00000227507 & G1/S-specific cyclin-D1 (PRAD1 oncogene) & CCND1 & $1.3^{*}$ \\
\hline 102813 & ENST00000372991 & G1/S-specific cyclin-D3 & $C C N D 3$ & 1.0 \\
\hline 101418 & ENST00000257904 & Cell division protein kinase 4 & $C D K 4$ & 1.0 \\
\hline 101427 & ENST00000265734 & Cell division protein kinase 6 & CDK6 & 1.0 \\
\hline 100848 & ENST00000262643 & G1/S-specific cyclin-E1 & CCNE1 & 1.0 \\
\hline 100850 & ENST00000308108 & G1/S-specific cyclin-E2 & $C C N E 2$ & 1.0 \\
\hline 101416 & ENST00000266970 & Cell division protein kinase 2 & $C D K 2$ & 1.0 \\
\hline 101538 & ENST00000267163 & Retinoblastoma-associated protein (pRb) & $R B 1$ & 1.0 \\
\hline 102827 & ENST00000343380 & Transcription factor E2F1 (E2F-1) & $E 2 F 1$ & 1.0 \\
\hline 102830 & ENST00000361729 & Transcription factor E2F2 (E2F-2) & $E 2 F 2$ & 1.0 \\
\hline 102834 & ENST00000346618 & Transcription factor E2F3 (E2F-3) & $E 2 F 3$ & $1.2 *$ \\
\hline 101524 & ENST00000379160 & Proliferating cell nuclear antigen (PCNA) & $P C N A$ & $1.2 *$ \\
\hline \multicolumn{5}{|c|}{ G2/M phase } \\
\hline 102811 & ENST00000274026 & Cyclin-A2 (cyclin-A) & CCNA2 & $1.3 *$ \\
\hline 101373 & ENST00000256442 & G2/mitotic-specific cyclin-B1 & $C C N B 1$ & 1.1 \\
\hline 101376 & ENST00000288207 & G2/mitotic-specific cyclin-B2 & $C C N B 2$ & 1.0 \\
\hline 101406 & ENST00000293968 & Cell division control protein 2 homolog & $C D K 1$ & 1.0 \\
\hline 102820 & ENST00000302506 & M-phase inducer phosphatase 1 & $C D C 25 A$ & 1.0 \\
\hline 102823 & ENST00000245960 & M-phase inducer phosphatase 2 & $C D C 25 B$ & 1.15 \\
\hline 102826 & ENST00000323760 & M-phase inducer phosphatase 3 & $C D C 25 C$ & 1.0 \\
\hline 102849 & ENST00000299613 & Wee1-like protein kinase & WEE1 & 1.0 \\
\hline \multicolumn{5}{|c|}{ Cell cycle progresion inhibitors } \\
\hline 102909 & ENST00000244741 & Cyclin-dependent kinase inhibitor 1 (p21) & $P 21 C I P 1$ & $-1.9 * *$ \\
\hline 100855 & ENST00000228872 & $\begin{array}{l}\text { Cyclin-dependent kinase inhibitor 1B (cyclin-dependent } \\
\text { kinase inhibitor p27) }\end{array}$ & $P 27 K I P 1$ & $-1.2 *$ \\
\hline 101471 & ENST00000370986 & $\begin{array}{l}\text { Growth arrest and DNA-damage-inducible protein GADD45 } \\
\text { alpha (DNA-damage-inducible transcript 1) }\end{array}$ & $G A D D 45 A$ & $-1.2 *$ \\
\hline
\end{tabular}

Values are mean \pm SEM. $* * *$ Significantly different from control at $P<0.5$ and $P<0.001$, respectively. Control value $=1.0$

protein Apaf-1 $(A P A F 1)$ were noted. In addition, we measured a range of 1.3- to 2.2-fold suppression of caspases 3 (CASP3), 6 (CASP6), and 7 (CASP7), which are well-known effector caspases, and $C A D$ and $I C A D$, which are responsible for DNA fragmentation (all of these genes are involved in the intrinsic apoptotic pathway). Leptin had no effect on $B C L 2, B C L W, B C L X$, or MCL1 levels (pro-survival genes), whereas a range of 1.2- to 2.1-fold suppression of $B A D, B A X, B A K 1, B I D$, and $B O K$ (proapoptotic genes) was observed. We also noted no change in the levels of the endonuclease $\mathrm{G}(E N D O G)$ genes involved in CAD-independent DNA fragmentation or in the tumorsuppressor gene p53 (TP53) $(P<0.05, \quad P<0.01$, $P<0.001$; Table 2).

Apoptotic protein expression analysis

The protein expression of $B A D, T N F R 1$, and CASP 6 , the apoptotic genes that showed the largest changes in gene expression level, was analyzed by western blot. Leptininduced inhibition of $\mathrm{Bad}$ (a component of the intrinsic pathway and a pro-apoptotic Bcl-2 family protein; $P<0.001$; Fig. 5b), TNFR1 (a component of the extrinsic pathway, tumor necrosis factor receptor $1 ; P<0.001$; Fig. 5a), and caspase 6 protein (executor caspases; $P<0.001$; Fig. 5c) expression was noted. The cleaved forms of caspase 6 were almost undetectable following leptin treatment.

\section{Discussion}

We evaluated the effects of leptin on cell proliferation and apoptosis in the human ovarian cancer cell line OVCAR-3. Because we found a dose-dependent stimulatory effect on cell proliferation and an inhibitory effect on apoptosis, we expected that the gene products involved in these processes would also be affected. 


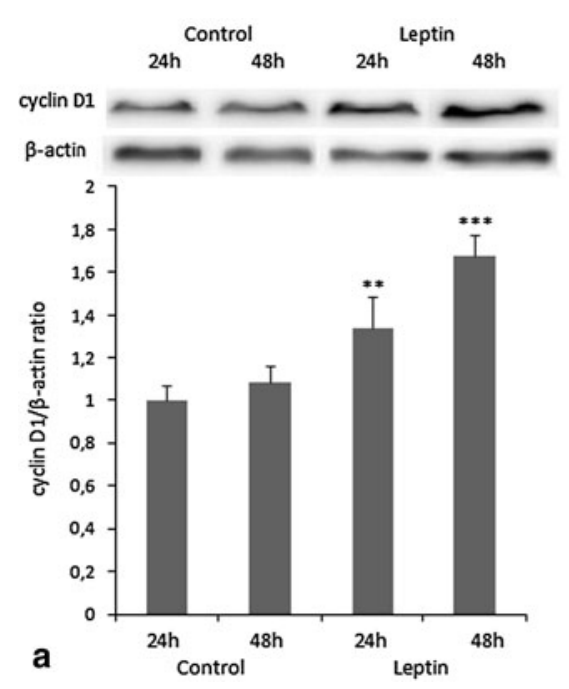

Fig. 3 Effects of leptin (40 ng/ml) on a cyclin D1 (36 kDa), b cyclin A $(55 \mathrm{kDa})$, and c p21WAF1/CIP1 (21 kDa) protein expression in OVCAR-3 cells. Cells were treated with leptin for 24 and 48 h. $\beta$ actin (42 kDa) served as the loading control, and densitometry values

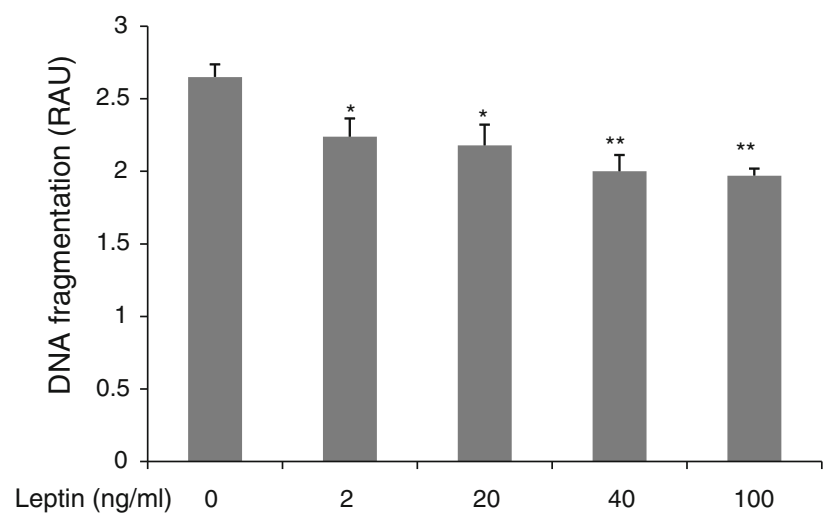

Fig. 4 Effects of leptin on DNA fragmentation in OVCAR-3 cells. Cells were treated with leptin at 2, 20, 40, and $100 \mathrm{ng} / \mathrm{ml}$ for $24 \mathrm{~h}$ and then analyzed with a Cellular DNA Fragmentation ELISA kit. RAU, relative absorbance units. Values are mean \pm S.E.M. $* * *$ Significantly different from control at $P<0.05$ and $P<0.01$, respectively

Effects on cell proliferation

Using the alamarBlue test, which is based on the detection of cellular metabolic activity, we defined a dose-dependent (from $2 \mathrm{ng} / \mathrm{ml}$ to $100 \mathrm{ng} / \mathrm{ml}$ ) stimulatory effect of leptin on OVCAR-3 cell proliferation. This observation is in agreement with Uddin et al. [13], who observed a dose-dependent (from $10 \mathrm{ng} / \mathrm{ml}$ ) stimulatory effect of leptin on proliferation of the ovarian epithelial cancer cell line MDAH2774. On the other hand, Choi et al. [11] showed that leptin at 1 and $10 \mathrm{ng} / \mathrm{ml}$ doses has no effect on human ovarian cancer BG-1 cell proliferation, but stimulates cell proliferation at doses of 100 and $1,000 \mathrm{ng} / \mathrm{ml}$.

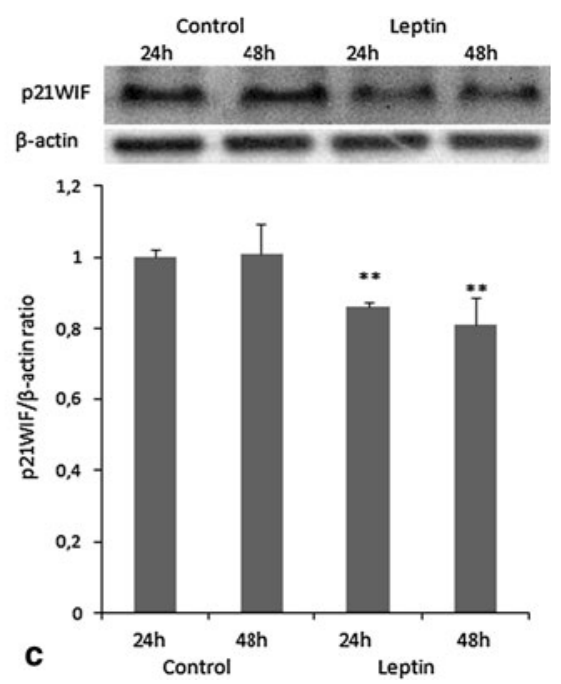

of cyclin D1, cyclin A, and p21WAF1/CIP1 bands were normalized to $\beta$-actin. Signal intensities are expressed in arbitrary units. The values are mean \pm SEM. $* * * * *$ Significantly different from control at $P<0.01$ and $P<0.001$, respectively

Flow cytometry analysis showed that leptin promotes cell cycle progression, as demonstrated by an increased cell population in both the $\mathrm{S}$ and $\mathrm{G} 2 / \mathrm{M}$ phases. Our results are consistent with Catalano et al. [16], who noted an increased number of Ishikawa human endometrial cancer cells in the $\mathrm{S}$ phase after $24 \mathrm{~h}$ of leptin treatment (100 and 1,000 $\mathrm{ng} /$ $\mathrm{ml})$. In addition, Chen et al. [17] observed that 48-h treatment of ZR-75-1 breast cancer cells with leptin (100 ng/ml) increases the cell population in both S and G2/ M phases.

Alterations of the mechanisms controlling cell cycle progression play a relevant role in the pathogenesis of different human neoplasias. Because the cell cycle is regulated by the coordinate action of cyclin-dependent kinases (cdks), specific cyclin proteins, and cdk inhibitors, we focused on the analysis of cell cycle-associated genes to gain insight into the mechanism of leptin's proliferative action. Using real-time PCR, we found that leptin $(40 \mathrm{ng} / \mathrm{ml})$ impacts proliferation by upregulating cell cycle progression genes and suppressing cell cycle inhibitor genes. We observed up-regulation of mRNAs for $C C N D 1, C C N A 2, P C N A$, and $E 2 F 3$ (genes responsible for inducing cell proliferation) and down-regulation of mRNAs for P21CIP1, P27KIP1, and GADD45A (genes responsible for inhibiting proliferation). Up-regulation of $C C N D 1$ and $C C N A 2$ and down-regulation of $P 21 C I P 1$, the most changed genes, were also observed at the protein level by western blot. Cyclin D1, an important cell cycle regulator, is required for completion of the G1/S transition in normal mammalian cells $[18,19]$ and is one of the most commonly affected proteins in abnormal states, such as cancer. Our results are consistent with previous studies showing similar leptin induction of cyclin D1 expression in human breast cancer $[16,17,20]$, the 
Table 2 Changes in selected apoptotic genes' expression in OVCAR-3 cells following exposure to $40 \mathrm{ng} / \mathrm{ml}$ leptin for $24 \mathrm{~h}$

\begin{tabular}{|c|c|c|c|c|}
\hline Assay ID & Transcript & Description & Gene symbol & $\begin{array}{l}\text { Average fold } \\
\text { change }\end{array}$ \\
\hline \multicolumn{5}{|c|}{ Extrinsic pathway } \\
\hline 102679 & ENST00000162749 & $\begin{array}{l}\text { Tumor necrosis factor receptor superfamily member } 1 \mathrm{~A} \text { precursor } \\
\text { (p60) }\end{array}$ & TNFR1 & $-1.8^{* * *}$ \\
\hline 100426 & ENST00000371875 & $\begin{array}{l}\text { Tumor necrosis factor receptor superfamily member } 6 \text { precursor } \\
\text { (FASLG receptor) }\end{array}$ & FAS & -1.1 \\
\hline 100417 & ENST00000301838 & Protein FADD (FAS-associated death domain protein) & $F A D D$ & $-1.54 * *$ \\
\hline 100289 & ENST00000332896 & $\begin{array}{l}\text { Death domain-containing protein CRADD (caspase and RIP adapter } \\
\text { with death domain) }\end{array}$ & $C R A D D$ & 1.0 \\
\hline 100227 & ENST00000358485 & Caspase- 8 precursor & CASP8 & -1.1 \\
\hline 100204 & ENST00000272879 & Caspase-10 precursor & CASP10 & $-1.45^{* *}$ \\
\hline 100210 & ENST00000310447 & Caspase-2 precursor & CASP2 & 1.0 \\
\hline \multicolumn{5}{|c|}{ Intrinsic pathway } \\
\hline \multicolumn{5}{|c|}{ Pro-survival } \\
\hline 100083 & ENST00000398117 & Apoptosis regulator $\mathrm{Bcl}-2$ & $B C L 2$ & 1.0 \\
\hline 104039 & ENST00000250405 & Apoptosis regulator $\mathrm{Bcl}-\mathrm{W}$ (Bcl-2-like 2 protein) & $B C L W$ & 1.0 \\
\hline 100088 & ENST00000307677 & Apoptosis regulator $\mathrm{Bcl}-\mathrm{X}$ (Bcl-2-like 1 protein) & $B C L X$ & 1.0 \\
\hline 102930 & ENST00000369026 & $\begin{array}{l}\text { Induced myeloid leukemia cell differentiation protein } \mathrm{Mcl}-1 \text { (Bcl-2- } \\
\text { related protein EAT/mcl1) }\end{array}$ & MCL1 & 1.0 \\
\hline \multicolumn{5}{|c|}{ Pro-apoptotic } \\
\hline 104034 & ENST00000394532 & $\mathrm{Bcl} 2$ antagonist of cell death (BAD) & $B A D$ & $-2.1 * * *$ \\
\hline 100068 & ENST00000374467 & Bcl-2 homologous antagonist/killer (apoptosis regulator BAK) & $B A K 1$ & $-1.5^{* *}$ \\
\hline 102861 & ENST00000293288 & Apoptosis regulator BAX & $B A X$ & $-1.3^{*}$ \\
\hline 100122 & ENST00000342111 & BH3-interacting domain death agonist (BID) & $B I D$ & $-1.2 *$ \\
\hline 100126 & ENST00000216115 & Bcl-2-interacting killer (Apoptosis inducer NBK) & $B I K$ & 1.0 \\
\hline 100165 & ENST00000318407 & Bcl-2-related ovarian killer protein (Hbok) & BOK & $-1.8 * * *$ \\
\hline 100233 & ENST00000333868 & Caspase-9 precursor & CASP9 & $-1.2 *$ \\
\hline 102892 & ENST00000333991 & Apoptotic protease-activating factor 1 (Apaf-1) & $A P A F 1$ & $-1.8 * * *$ \\
\hline 100213 & ENST00000308394 & Caspase-3 precursor & CASP3 & $-1.3^{*}$ \\
\hline 100222 & ENST00000265164 & Caspase- 6 precursor & CASP6 & $-2.0 * * *$ \\
\hline 100224 & ENST00000369331 & Caspase-7 precursor & CASP7 & $-1.5^{* *}$ \\
\hline 102620 & ENST00000264705 & CAD protein & $C A D$ & $-1.25^{*}$ \\
\hline 102630 & ENST00000377038 & $\begin{array}{l}\text { DNA fragmentation factor subunit alpha (DNA fragmentation factor } \\
45 \mathrm{kDa} \text { subunit) }\end{array}$ & $I C A D$ & $-1.25^{*}$ \\
\hline \multicolumn{5}{|c|}{ Caspase-independent pathway } \\
\hline 102632 & ENST00000372642 & Endonuclease G, mitochondrial precursor & ENDOG & 1.0 \\
\hline 101277 & ENST00000396473 & Cellular tumor antigen p53 (Tumor suppressor p53) & TP53 & 1.0 \\
\hline
\end{tabular}

Values are mean \pm SEM. $* * * * * *$ Significantly different from control at $P<0.05, P<0.01$, and $P<0.001$, respectively. Control value $=1.0$

colon cancer cell line HT-29 [21], and human hepatocarcinoma cells [22]. As cells progress into the $\mathrm{S}$ phase, cyclin $\mathrm{A}$ is expressed and becomes the primary cyclin associated with cdk2. Overexpression of cyclin A has been indicated in various human tumors, including breast [23], prostate [24], and ovarian cancer $[25,26]$. To the best of our knowledge, this is the first report of leptin induction of cyclin A expression in human ovarian cancer cells. In the present study, we observed suppression of $\mathrm{p} 21 \mathrm{WAF} 1 / \mathrm{CIP} 1$, which acts as a universal inhibitor of cdks, and arrests the cell cycle at both G1/S and G2/M restriction points [27]. Our results are consistent with previous studies showing a similar decrease in p21WAF1/ CIP1 expression under the influence of leptin in human breast cancer cells [17] and Ishikawa human endometrial cancer cells [16]. Furthermore, low levels of p21WAF1/CIP1 have been shown to be a marker of poor overall survival in ovarian cancer patients [28]. Down-regulation or inactivation of the cdk inhibitors, including p21CIP1, p27KIP1, and p16INK4a, which normally cause G1 arrest by binding to cyclin-cdk complexes, is often observed in a variety of human tumors, rendering the cell susceptible to uncontrolled extracellular proliferation signals [29]. 

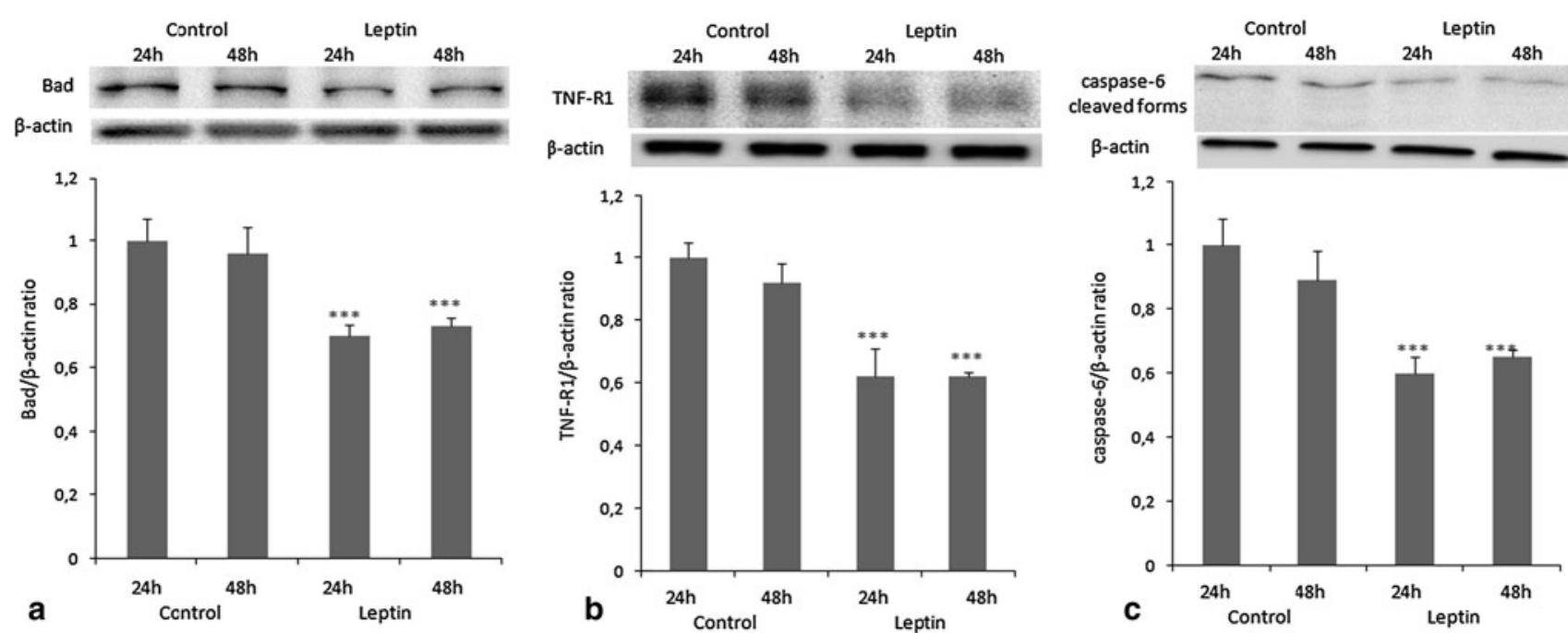

Fig. 5 Effects of leptin $(40 \mathrm{ng} / \mathrm{ml})$ on a Bad (23 kDa), b TNFR1 $(55 \mathrm{kDa})$, and c caspase $6(35,15 \mathrm{kDa})$ protein expression in OVCAR-3 cells. Cells were treated with leptin for 24 and 48 h. $\beta$ actin $(42 \mathrm{kDa})$ served as the loading control, and densitometry of

TNFR1, Bad, and caspase 6 bands were normalized to $\beta$-actin. Signal intensities are expressed in arbitrary units. Values are mean \pm SEM. *** Significantly different from control at $P<0.001$

To summarize, we suggest that leptin may promote progression from $\mathrm{G} 1$ to $\mathrm{S}$ phase by stimulating expression of cyclin D1 and inhibiting that of p21WAF1/CIP1, as well as progression to the $\mathrm{S}$ phase by stimulating the expression of cyclin A in an ovarian cancer cell line.

\section{Action on cell apoptosis}

A perturbation of the balance between cell proliferation and apoptosis has been suggested to play a significant role in mediating tumor progression. Surprisingly, data concerning the anti-apoptotic actions of leptin in ovarian cancer cells are limited. Herein, we observed that leptin inhibits OVCAR-3 cell apoptosis in a dose-dependent manner, as measured by DNA fragmentation. To our knowledge, there has been only one study addressing leptin in ovarian cancer cells [13], which showed that $100 \mathrm{ng} / \mathrm{ml}$ of leptin significantly prevents serum-starved apoptosis in the ovarian epithelial cancer cell lines SKOV-3 and MDAH2774. In previously published data, using physiologically relevant ovarian tissue, we illustrated the inhibitory action of leptin on cell apoptosis in pig ovarian follicles [30] and the developing corpus luteum [31]. There are also data showing an anti-apoptotic effect of leptin in breast cancer cell lines [7].

Cells undergo apoptosis through two major pathways: the extrinsic (death receptor) pathway and the intrinsic (mitochondrial) pathway. A hallmark of apoptosis is fragmentation of nuclear DNA. This process involves the caspase 3-dependent DNase CAD or can occur independently of caspase activity. In the present study, we found that $40 \mathrm{ng} / \mathrm{ml}$ of leptin acts by suppressing the expression of pro-apoptotic genes, such as TNFR1, FADD, CASP3, 6, 7, 9, and 10, CAD, ICAD, BAX, BAD, BAK1, BID, BOK, and APAF1. TNFR1, BAD, and CASP6 were the most down-regulated genes, and these changes were also observed at the protein level, as measured by western blot. Using a gene microarray, Perera et al. [32] observed that in MCF-7 cells, leptin $(500 \mathrm{ng} / \mathrm{ml})$ induces the expression of anti-apoptotic genes $B C L 2$ and survivin and reduces the expression of other apoptotic genes (TRAF-interacting protein and TRADD) involved in the tumor necrosis factor (TNF)-induced apoptotic pathway. Their observation is partially consistent with our results, suggesting that leptin suppresses the TNF-induced extrinsic apoptosis pathway. Our data further showed suppression of TNFR1 at both the gene and protein expression levels. The leptin-induced reduction of Bax protein expression in T47-D breast cancer cells observed by Nkhata et al. [33], and in BAX gene expression observed here in OVCAR-3 cells, suggests that leptin also acts on the intrinsic apoptotic pathway. Downregulation of TGFB1-induced Bax expression in hepatocarcinoma cells was described by Chen et al. [22]. Both apoptotic pathways lead to activation of the executioner caspases, caspase 3,6 , and 7 , which are the main proteases degrading the cell. To the best of our knowledge, we are the first to show down-regulation of caspase 6 (executor caspase) at the gene and protein levels. Jiang et al. [34] showed leptin suppression of docetaxel-induced apoptosis in MCF-7 breast cancer cells via inhibition of caspase 9 activity, indirectly confirming our results. Similar to caspase 6, we observed inhibition of caspase 3 and caspase 7 mRNA expression by leptin, suggesting that leptin inhibits caspase-dependent apoptosis. Thus, we suggest that leptin 
prevents caspase-dependent apoptosis in OVCAR-3 cells by down-regulating pro-apoptotic proteins in both extrinsic (TNFR1) and intrinsic (BAD, caspase 6) apoptosis pathways.

In conclusion, our results are the first to demonstrate the molecular mechanism involved in the regulation of the cell cycle and apoptosis by leptin in an epithelial ovarian cancer cell line. The combination of proliferative and antiapoptotic effects, by up-regulating genes and proteins responsible for inducing cell proliferation as well as downregulating pro-apoptotic genes and proteins in the apoptotic pathways, clarifies the role of leptin signaling in the progression of ovarian cancer. Taking into consideration the limitations of in vitro studies, in vivo studies should be performed to confirm leptin's contribution to ovarian cancer progression.

Funding This work was supported by the Polish Committee for Scientific Research from 2010 to 2013 as project 0050/B/P01/2010/38 (Poland).

Conflict of interest The authors declare that there is no conflict of interest that could be perceived as prejudicing the impartiality of the reported research.

Open Access This article is distributed under the terms of the Creative Commons Attribution License which permits any use, distribution, and reproduction in any medium, provided the original author(s) and the source are credited.

\section{References}

1. M.E. Grossmann, A. Ray, K.J. Nkhata, D.A. Malakhov, O.P. Rogozina, S. Dogan, M.P. Cleary, Obesity and breast cancer: status of leptin and adiponectin in pathological processes. Cancer Metastasis Rev. 29, 6416-6453 (2010)

2. M. Owecki, E. Nikisch, A. Miczke, D. Pupek-Musialik, J. Sowiński, Leptin, soluble leptin receptors, free leptin index, and their relationship with insulin resistance and BMI: high normal BMI is the threshold for serum leptin increase in humans. Horm. Metab. Res. 42, 585-589 (2010)

3. P.J. Havel, S. Kasim-Karakas, W. Mueller, P.R. Johnson, R.L. Gingerich, J.S. Stern, Relationship of plasma leptin to plasma insulin and adiposity in normal weight and overweight women: effects of dietary fat content and sustained weight loss. J. Clin. Endocrinol. Metab. 81, 4406-4413 (1996)

4. E. Kimura, K. Matsumoto, T. Samori, S. Kato, T. Kawahara, One-step enzyme-linked immunosorbent assay (ELISA) for measurement of serum free leptin. Clin. Chim. Acta 296, 45-57 (2000)

5. I. Knerr, D. Herzog, M. Rauh, W. Rascher, T. Horbach, Leptin and ghrelin expression in adipose tissues and serum levels in gastric banding patients. Eur. J. Clin. Invest. 36, 389-394 (2006)

6. C. Garofalo, E. Surmacz, Leptin and cancer. J. Cell. Physiol. 207, 12-22 (2006)

7. T. Jardé, S. Perrier, M.P. Vasson, F. Caldefie-Chézet, Molecular mechanisms of leptin and adiponectin in breast cancer. Eur. J. Cancer 47, 33-43 (2011)

8. C.M. Olsen, A.C. Green, D.C. Whiteman, S. Sadeghi, F. Kolahdooz, P.M. Webb, Obesity and the risk of epithelial ovarian cancer: a systematic review and meta-analysis. Eur. J. Cancer 43, 690-709 (2007)

9. L.J. Schouten, C. Rivera, D.J. Hunter, D. Spiegelman, H.O. Adami, A. Arslan, W.L. Beeson, P.A. van den Brandt, J.E. Buring, A.R. Folsom et al., Height, body mass index, and ovarian cancer: a pooled analysis of 12 cohort studies. Cancer Epidemiol. Biomarkers 17, 902-912 (2008)

10. M.F. Leitzmann, C. Koebnick, K.N. Danforth, L.A. Brinton, S.C. Moore, A.R. Hollenbeck, A. Schatzkin, J.V. Lacey Jr, Body mass index and risk of ovarian cancer. Cancer 115, 812-822 (2009)

11. J.H. Choi, S.H. Park, P.C. Leung, K.C. Choi, Expression of leptin receptors and potential effects of leptin on the cell growth and activation of mitogen-activated protein kinases in ovarian cancer cells. J. Clin. Endocrinol. Metab. 90, 207-210 (2005)

12. J.H. Choi, K.T. Lee, P.C. Leung, Estrogen receptor alpha pathway is involved in leptin-induced ovarian cancer cell growth. Carcinogenesis 32, 589-596 (2011)

13. S. Uddin, R. Bu, M. Ahmed, J. Abubaker, F. Al-Dayel, P. Bavi, K.S. Al-Kuraya, Overexpression of leptin receptor predicts an unfavorable outcome in Middle Eastern ovarian cancer. Mol. Cancer 8, 74 (2009)

14. A. Ptak, E.L. Gregoraszczuk, Bisphenol A induces leptin receptor expression, creating more binding sites for leptin, and activates the JAK/Stat, MAPK/ERK and PI3K/Akt signalling pathways in human ovarian cancer cell. Toxicol. Lett. 210, 332-337 (2012)

15. G. Tellmann, The E-method: a highly accurate technique for gene-expression analysis. Nat. Methods 3 (2006). doi:10.1038/ nmeth894

16. S. Catalano, C. Giordano, P. Rizza, G. Gu, I. Barone, D. Bonofiglio, F. Giordano, R. Malivindi, D. Gaccione, M. Lanzino et al., Evidence that leptin through STAT and CREB signaling enhances cyclin D1 expression and promotes human endometrial cancer proliferation. J. Cell. Physiol. 218, 490-500 (2009)

17. C. Chen, Y.C. Chang, C.L. Liu, K.J. Chang, I.C. Guo, Leptininduced growth of human ZR-75-1 breast cancer cells is associated with up-regulation of cyclin D1 and c-Myc and downregulation of tumor suppressor p53 and p21WAF1/CIP1. Breast Cancer Res. Treat. 98, 121-132 (2006)

18. M. Fu, C. Wang, Z. Li, T. Sakamaki, R.G. Pestell, Minireview: cyclin D1: normal and abnormal functions. Endocrinology 145, 5439-5447 (2004)

19. K.E. Knudsen, J.A. Diehl, C.A. Haiman, E.S. Knudsen, Cyclin D1: polymorphism, aberrant splicing and cancer risk. Oncogene 25, 1620-1628 (2006)

20. N.K. Saxena, P.M. Vertino, F.A. Anania, D. Sharma, Leptininduced growth stimulation of breast cancer cells involves recruitment of histone acetyltransferases and mediator complex to CYCLIN D1 promoter via activation of Stat3. J. Biol. Chem. 282, 13316-13325 (2007)

21. P. Rouet-Benzineb, T. Aparicio, S. Guilmeau, C. Pouzet, V. Descatoire, M. Buyse, A. Bado, Leptin counteracts sodium butyrate-induced apoptosis in human colon cancer HT-29 cells via NF-kappaB signaling. J. Biol. Chem. 279, 16495-16502 (2004)

22. C. Chen, Y.C. Chang, C.L. Liu, T.P. Liu, K.J. Chang, I.C. Guo, Leptin induces proliferation and anti-apoptosis in human hepatocarcinoma cells by up-regulating cyclin D1 and down-regulating Bax via a Janus kinase 2-linked pathway. Endocr. Relat. Cancer 14, 513-529 (2007)

23. H. Kawamoto, H. Koizumi, T. Uchikoshi, Expression of the G2-M checkpoint regulators cyclin $\mathrm{B} 1$ and $\mathrm{cdc} 2$ in nonmalignant and malignant human breast lesions: immunocytochemical and quantitative image analyses. Am. J. Pathol. 150, 15-23 (1997)

24. R.D. Mashal, S. Lester, C. Corless, J.P. Richie, R. Chandra, K.J. Propert, A. Dutta, Expression of cell cycle-regulated proteins in prostate cancer. Cancer Res. 56, 4159-4163 (1996) 
25. N. Barboule, V. Baldin, S. JOzan, S. Vidal, A. Valette, Increased level of p21 in human ovarian tumors is associated with increased expression of cdk2, cyclin A and PCNA. Int. J. Cancer 76, 891-896 (1998)

26. B.S. Yoon, Y.T. Kim, S. Kim, C.S. Lee, J.W. Kim, J.H. Kim, S.W. Kim, N.H. Cho, Prognostic value of nuclear DNA quantification and cyclin A expression in epithelial ovarian carcinoma. Eur. J. Obstet. Gynecol. Reprod. Biol. 136, 110-115 (2008)

27. Y. Xiong, G.J. Hannon, H. Zhang, D. Casso, R. Kobayashi, D. Beach, p21 is a universal inhibitor of cyclin kinases. Nature 366, 701-704 (1993)

28. A. Bali, P.M. O'Brien, L.S. Edwards, R.L. Sutherland, N.F. Hacker, S.M. Henshall, Cyclin D1, p53, and p21Waf1/Cip1 expression is predictive of poor clinical outcome in serous epithelial ovarian cancer. Clin. Cancer Res. 10, 5168-5177 (2004)

29. C.J. Sherr, J.M. Roberts, CDK inhibitors: positive and negative regulators of G1-phase progression. Gene. Dev. 13, 1501-1512 (1999)
30. E.L. Gregoraszczuk, A. Rak, A. Wójtowicz, A. Ptak, T. Wojciechowicz, K.W. Nowak, Gh and IGF-I increase leptin receptor expression in prepubertal pig ovaries: the role of leptin in steroid secretion and cell apoptosis. Acta Vet. Hung. 54, 413-426 (2006)

31. E.Ł. Gregoraszczuk, A. Ptak, In vitro effect of leptin on growth hormone (GH)- and insulin-like growth factor-I (IGF-I)-stimulated progesterone secretion and apoptosis in developing and mature corpora lutea of pig ovaries. J. Reprod. Dev. 51, 727-733 (2005)

32. C.N. Perera, H.G. Chin, N. Duru, I.G. Camarillo, Leptin-regulated gene expression in MCF-7 breast cancer cells: mechanistic insights into leptin-regulated mammary tumor growth and progression. J. Endocrinol. 199, 221-233 (2008)

33. K.J. Nkhata, A. Ray, T.F. Schuster, M.E. Grossmann, M.P. Cleary, Effects of adiponectin and leptin co-treatment on human breast cancer cell growth. Oncol. Rep. 21, 1611-1619 (2009)

34. H. Jiang, J. Yu, H. Guo, H. Song, S. Chen, Upregulation of survivin by leptin/STAT3 signaling in MCF-7 cells. Biochem. Biophys. Res. Commun. 368, 1-5 (2008) 